\title{
Palynostratigraphy and Paleoclimate of the Sequences Penetrated by Meren 31 Side Tract-2 Well, Offshore Niger Delta
}

\author{
Peter S. Ola, Bamisile K. Adewale \\ Department of Applied Geology, Futa, Nigeria \\ Email: psola@futa.edu.ng
}

Received 9 May 2014; revised 3 June 2014; accepted 28 June 2014

Copyright (C) 2014 by authors and Scientific Research Publishing Inc.

This work is licensed under the Creative Commons Attribution International License (CC BY). http://creativecommons.org/licenses/by/4.0/

\section{(c) (i) Open Access}

\begin{abstract}
Palynological study of an offshore well in the Niger delta was carried out to document the palynomorphs assemblage and subsequently date and establish paleoclimatic conditions in a portion of the Niger delta. One hundred and thirty seven cutting samples provided by Chevron Nigeria Plc were composited at $27 \mathrm{~m}$ interval for the study. The samples yielded forty six palynomorphs, which include Racemonocolpites hians, Zonocostites ramonae, Monoporites annulatus, Botryococcusbraunii, dinocyst Lycopodiumsporites spp., Pachydermitesdiederixi and Psilatricolporitescrassus. A Middle-Late Miocene age belonging to P800 and P700 zones of Germeraad was established for the interval studied. There were clear crests and troughs in the microfloral abundance indicative of alternations of dry and wet climatic conditions during the deposition of the Agbada Formation.
\end{abstract}

\section{Keywords}

Paleoclimate, Meren field, Agbada Formation, Racemonocolpites hians

\section{Introduction}

Meren 31st-2 is one of several development wells drilled in Meren field in oil mining lease (OML)-95 of Chevron Nigeria Limited (Figure 1). The well was drilled to a total depth of $2758 \mathrm{~m}$ and located on Longitude $4^{\circ} 50^{\prime}$ and Latitude 558' E (N 193335.92; E 273519.3) in the Western part of Niger Delta, West coast of Africa. Several publications directed towards exploration and exploitation of hydrocarbon abound on this prolific oil field. Recent publications particularly [1] on flow units, connectivity, and reservoir characterization of the field revealed that Meren field consists of complex reservoir architecture characterized by shoreface clinoforms and a history of progradation and retrogradation cycles. A high resolution sequence stratigraphic and reservoir 


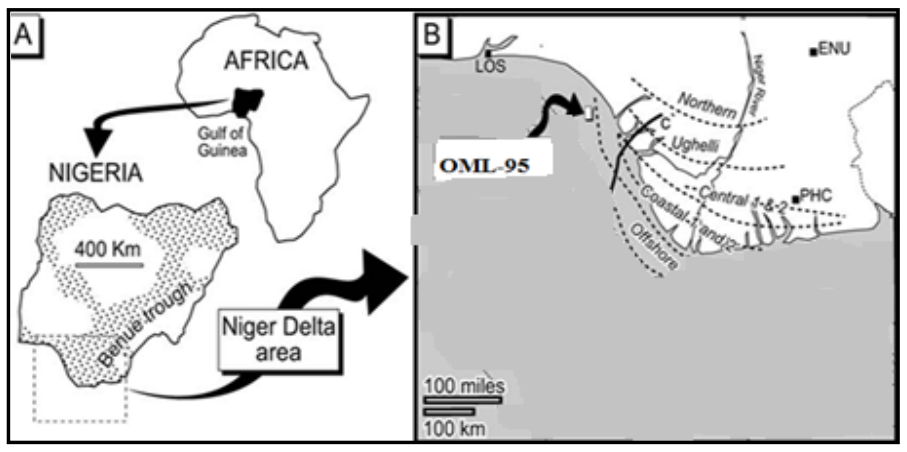

Figure 1. Location of OML 95 containing Meren Field is situated.

characterization of some sand units in the field had been carried out [2]. No previous investigation on miospore assemblage from Meren field has been made public. However, some miospores have been reported to occur in the Niger delta and used for both stratigraphic and climatic studies. For example Podocarpus milanjianus marked the boundary between Benin and Agbada Formations of the Niger Delta [3]. Twenty nine informal palynological zonations of the Niger Delta using alphanumerical coding system [4] appear to form the background information for in-house zonal scheme of Shell Petroleum Development Company. Using detailed morphological analysis of pollen groups which were assigned to the genera Praedapollis, Striamonocolpites, Arecipites, Spirosyncolpites, Racemonocolpites, Verrutricolpites, Retibrevitricolporites and Belskipollis, a refinement of the palynostratigraphic zonation and correlation of the Neogen of the Niger Delta was established [5]. The pollen grains of a $36 \mathrm{~m}$ deep core from Niger Delta were analyzed [6] to reach a conclusion that in the Quaternary, there were shifts in the extent of rain forest and savanna with the latter replacing the formal. Paleoenvironmental analysis of a section Niger Delta Basin (Ogbomotoru-1 well) (Figure 1) was used to infer transitional environment of deposition with marine interference based on the abundance of Zonocostrites ramonae, and occurrence of Crassoretitriletes vanraadshooveni, Magnasriatites bowardii and Pachydermites diederixi savannah [7].

The primary focus of this work is to establish the palynomorph contents, their palaecology and paleoclimate as well as the environment of deposition of the strata penetrated by Meren 31st-2. It is envisaged that the result shall add to information on the miospores recoverable from the western portion of the Niger delta and assist in the ongoing refining of the zonal scheme for the Niger delta.

\section{Geological Setting}

The Niger delta is the most significant hydrocarbon province on the West African continental margin. It started to evolve in Eocene times and deposition is still ongoing offshore. Three main formations have been recognized in the subsurface of the Delta [8]-[13]. These are the Benin, Agbada and Akata Formations. These formations were deposited in continental, transitional and marine environments, respectively; together they form a thick, overall progradational passive-margin wedge [2].

The Akata Formation is the basal unit composed mainly of marine shales believed to be the main source rock within the basin. The Agbada Formation is made up of alternating sandstone, siltstone and shale sequences that constitute the petroleum reservoirs of the basin. On the other hand, the Benin Formation largely consists of non-marine sands with a few shaly intercalations [2].

\section{Materials and Methods}

A total of one hundred and thirty seven ditch cutting samples (which were composited to forty six samples) used for this study was provided by Chevron Nigeria Plc. From each sample, about 25 gm was weighed and thoroughly washed/cleaned. The pretreatment of the samples with various acid combinations include removal of unwanted carbonate material by washing with $10 \mathrm{ml}$ diluted hydrochloric acid as well as further treating the residue with $60 \%$ hydrofluoric acid and boiling hydrochloric to dissolve/remove all silicates and silicofluoride gel respectively. The ultrasonic centrifuge machine was used to further separate out the dissolved material (i.e. dirt, clay, mud etc.) from the organic matter residue for 2 minutes. Subsequently, three drops of Canada balsam in Xylene on the slide and mixed thoroughly allow for proper mixing and then pipette into a cover slip glass slide 
on top of the hot plate until dryness and was ready for palynological microscopic evaluation.

The prepared slides for palynomorphs were studied under DP12 Olympus microscope, identification and description were attempted for as many palynomorphs as possible using relevant literature. Photographing of the well preserved palynomorphs was done using attached DP12 Olympus microscope camera.

\section{Results}

The stratigraphic distribution of fifty-six (56) pollen and spore species used for the palynological biozonation and palaeoclimatic interpretation of Meren 31 is shown in Figure 2 and Table 1, Table 2, Table 3, and Table 4. The sediments in this section yielded a rich assemblage of the under listed pollens, spores and dinocysts species. The pollens are: Monoporites annulatus, Zonocostites ramonae, Corylus spp., Germamonoporites spp., Pachydermites diederixi, Corsiripollerites jussiaeneses, Psilatricoporites crassus, Retibrevitricolporites spp., Arecipites spp., Canthium spp., Nymphaeopolis clarus, Sapotaceideapollentes spp., Soleginelle myosporus, Belskipolis elegans, Cyperaceapolis spp., Polypodiaceisporites spp., Psilatricoporites onitshenesis, Retricoporiteds irregularis, Striatricopites catalubus, Racemonocolpites hians, Retibrevicolporites protudens, Retrimonocolporites obensis, Sapoteceae, Magnastriatites howardi, Verrutricolporites rotudiporus, Multriaraolites formusus, Proteacidites cooksonii, Pteris spp., Concentricysts spp., Echistephanosporites echinatus, Podocarpyldites spp., Gemmate pollen, Retibrevitricolporites obodensis, Echnperylporites estalea, Pollen indeterminate, Psilatricolpites spp, Nummulpolis concinnus, Retricolporites spp, Charred graminacea cuticle and Psilamonocolpites spp.

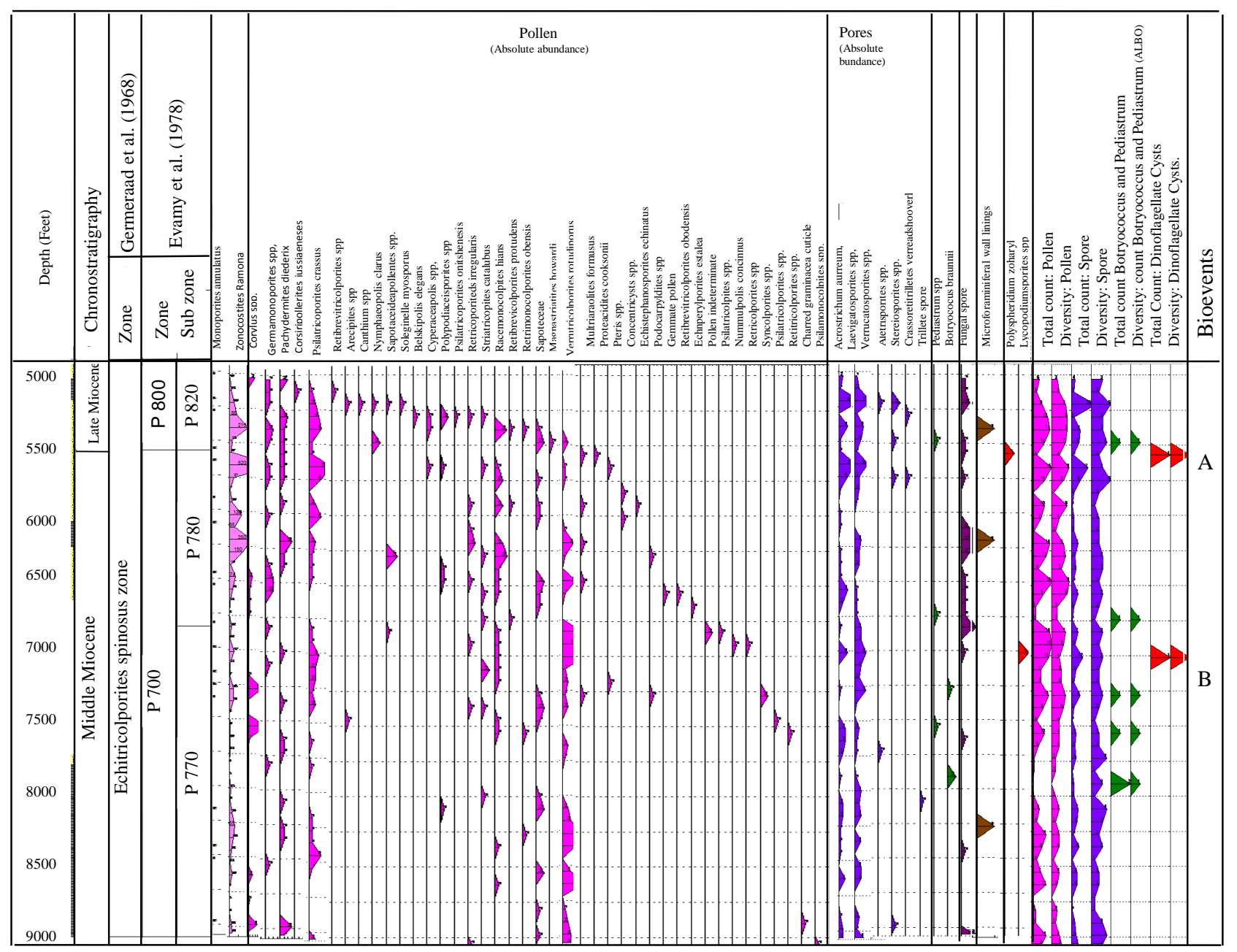

Bioevents: A = Top regular occurrence of Racemonocolpites hians; B = Quantitative Top Occurrence of Vertricolporites rotundiporouss) 
Table 1. Meren 31st-2 well ecological groups abundance.

\begin{tabular}{|c|c|c|c|c|c|c|c|c|c|c|c|}
\hline DEPTH (m) & FWSP & DIV & BWSP & DIV & SAVANN & DIV & RAIN & DIV & OTHERS & MONT & BEACH \\
\hline $1507-1533$ & 5 & 4 & 2 & 1 & 4 & 2 & 2 & 1 & - & - & - \\
\hline $1533-1561$ & 3 & 2 & - & - & - & - & 2 & 2 & 2 & - & - \\
\hline $1561-1588$ & 17 & 5 & 2 & 1 & 5 & 2 & 3 & 3 & - & - & - \\
\hline $1588-1615$ & 5 & 4 & 5 & 2 & 3 & 3 & 1 & 1 & 2 & - & - \\
\hline $1615-1643$ & 9 & 5 & 5 & 2 & 1 & 1 & 6 & 2 & 1 & - & - \\
\hline $1643-1670$ & 15 & 7 & 2 & 2 & - & - & 3 & 2 & - & - & - \\
\hline $1670-1698$ & 3 & 3 & 3 & 3 & 2 & 1 & 2 & 2 & - & - & - \\
\hline $1698-1725$ & 15 & 7 & 8 & 2 & 2 & 1 & 9 & 3 & - & - & - \\
\hline $1725-1753$ & 7 & 6 & 5 & 2 & - & - & 6 & 2 & 1 & - & - \\
\hline $1753-1780$ & 2 & 1 & - & - & 1 & - & 1 & 1 & - & - & - \\
\hline $1780-1807$ & 3 & 3 & 3 & 2 & 1 & 1 & 5 & 4 & - & - & - \\
\hline $1807-1835$ & 4 & 3 & 4 & 1 & 1 & 1 & 1 & 1 & - & - & - \\
\hline $1835-1862$ & 3 & 2 & - & - & 2 & 1 & 3 & 1 & - & - & - \\
\hline $1862-1890$ & 11 & 3 & 5 & 2 & - & - & 5 & 3 & - & - & - \\
\hline 1890 - 1917 & 8 & 5 & 2 & 2 & - & - & 4 & 2 & - & 1 & - \\
\hline 1917 - 1944 & 6 & 4 & 2 & 2 & - & - & 2 & 2 & - & - & - \\
\hline $1944-1972$ & 11 & 6 & 1 & 1 & 4 & 3 & 4 & 4 & - & - & - \\
\hline 1972 - 1999 & 10 & 7 & - & - & 2 & 2 & 5 & 2 & - & - & - \\
\hline 1999 - 2027 & 2 & 2 & - & - & 1 & 1 & 2 & 1 & - & - & 1 \\
\hline 2027 - 2054 & 3 & 3 & - & - & 4 & 1 & - & - & - & - & - \\
\hline $2054-2082$ & 15 & 5 & 1 & 1 & 3 & 2 & 2 & 2 & 1 & - & - \\
\hline $2082-2109$ & 3 & 3 & 1 & 1 & - & - & 1 & 1 & 1 & - & - \\
\hline $2109-2137$ & 17 & 4 & 2 & 2 & 3 & 1 & 5 & 2 & - & - & - \\
\hline 2137 - 2164 & 9 & 5 & 2 & 1 & - & - & 1 & 1 & - & - & - \\
\hline 2164 - 2192 & 5 & 3 & 2 & 1 & 4 & 3 & 1 & 1 & - & - & - \\
\hline $2192-2219$ & 12 & 5 & 1 & 1 & 8 & 2 & 2 & 2 & - & 1 & - \\
\hline 2219 - 2246 & 8 & 5 & 3 & 2 & 1 & 1 & 1 & 1 & 1 & - & - \\
\hline $2246-2274$ & 2 & 2 & 1 & 1 & - & - & 2 & 2 & - & - & - \\
\hline $2274-2301$ & 2 & 1 & - & - & 7 & 1 & 5 & 2 & 1 & - & - \\
\hline $2301-2329$ & 3 & 2 & 2 & 2 & 1 & 1 & 3 & 1 & - & - & - \\
\hline $2329-2356$ & 4 & 4 & 1 & 1 & - & - & 2 & 1 & - & - & - \\
\hline $2356-2384$ & 2 & 2 & 1 & 1 & - & - & - & - & - & - & - \\
\hline $2384-2410$ & 2 & 2 & - & - & - & - & 1 & 1 & - & - & - \\
\hline $2410-2438$ & 5 & 3 & - & - & - & - & - & - & - & - & - \\
\hline 2438 - 2466 & 9 & 5 & 1 & 1 & - & - & 2 & 1 & 1 & - & - \\
\hline 2466 - 2493 & 7 & 3 & 1 & 1 & 2 & 2 & 2 & 1 & - & - & - \\
\hline $2893-2521$ & 9 & 2 & 2 & 2 & - & - & 1 & 1 & 1 & - & - \\
\hline $2521-2548$ & 7 & 2 & 2 & 2 & - & - & 2 & 2 & - & - & - \\
\hline $2548-2576$ & - & - & 4 & 1 & 2 & 1 & 1 & 1 & - & - & - \\
\hline $2576-2603$ & 11 & 5 & 1 & 1 & - & - & - & - & - & - & - \\
\hline $2603-2630$ & 11 & 2 & - & - & 2 & 1 & 4 & 2 & - & - & - \\
\hline $2630-2658$ & 1 & 1 & - & - & - & - & - & - & - & - & - \\
\hline $2658-2685$ & 3 & 3 & - & - & 1 & 1 & - & - & - & - & - \\
\hline $2685-2713$ & 5 & 3 & - & - & 1 & 1 & - & - & - & - & - \\
\hline $2713-2740$ & 7 & 5 & 2 & 1 & 6 & 2 & 2 & 1 & - & - & - \\
\hline $2740-2758$ & 8 & 3 & 3 & 2 & - & - & 2 & 1 & 2 & 2 & - \\
\hline
\end{tabular}

FWSP = Fresh water swamp species; BWSP = Brackish water swamp species; SAVANN = Savannah species; RAIN = Lowland rainforest species; MONT $=$ Montane species; BEACH $=$ Beach vegetation; DIV $=$ No of species. 
Table 2. Fresh water algae and marine element composition Meren 31st-2 well.

\begin{tabular}{|c|c|c|c|c|}
\hline DEPTH (m) & BOTRYO & FUNGAL & DINO & $\mathrm{D} / \mathrm{B}$ \\
\hline 1507 - 1533 & - & 1 & - & - \\
\hline $1533-1561$ & - & 1 & - & - \\
\hline 1561 - 1588 & - & 2 & - & - \\
\hline $1643-1670$ & 1 & 1 & - & - \\
\hline 1670 - 1698 & - & 1 & 1 & - \\
\hline $1698-1725$ & - & - & - & - \\
\hline 1725 - 1753 & - & 1 & - & - \\
\hline $1753-1780$ & - & - & - & - \\
\hline $1780-1807$ & - & - & - & - \\
\hline $1807-1835$ & - & 2 & - & - \\
\hline 1835 - 1862 & - & 2 & - & - \\
\hline 1862 - 1890 & - & 2 & - & - \\
\hline 1917 - 1944 & - & 1 & - & - \\
\hline 1944 - 1972 & - & 1 & - & - \\
\hline 1972 - 1999 & - & 1 & - & - \\
\hline 1999 - 2027 & 1 & 1 & - & - \\
\hline 2027 - 2054 & - & 3 & - & - \\
\hline 2054 - 2082 & - & - & - & - \\
\hline $2082-2109$ & - & 1 & 1 & - \\
\hline 2109 - 2137 & - & - & - & - \\
\hline 2137 - 2164 & - & - & - & - \\
\hline $2164-2192$ & 1 & - & - & - \\
\hline $2192-2219$ & - & - & - & - \\
\hline 2219 - 2246 & - & - & - & - \\
\hline 2246 - 2274 & 1 & - & - & - \\
\hline $2274-2301$ & - & 1 & - & - \\
\hline 2301 - 2329 & - & - & - & - \\
\hline $2329-2356$ & - & - & - & - \\
\hline 2356 - 2384 & 2 & - & - & - \\
\hline $2384-2410$ & - & - & - & - \\
\hline 2410 - 2438 & - & - & - & - \\
\hline 2438 - 2466 & - & - & - & - \\
\hline 2466 - 2493 & - & - & - & - \\
\hline 2893 - 2521 & - & - & - & - \\
\hline 2521 - 2548 & - & 1 & - & - \\
\hline 2548 - 2576 & - & - & - & - \\
\hline 2685 - 2713 & - & - & - & - \\
\hline 2713 - 2740 & - & 3 & - & - \\
\hline $2740-2758$ & - & - & - & - \\
\hline
\end{tabular}


Table 3. Monoporites annulatus and Zonocostites composition of Meren 31st-2 well.

\begin{tabular}{|c|c|c|c|c|c|}
\hline DEPTH (m) & MONO & ZONO & TOTAL & \%MONO & \%ZONO \\
\hline $1507-1533$ & 1 & 10 & 11 & 9.1 & 90.9 \\
\hline $1533-1561$ & - & 23 & 23 & 0.0 & 100.0 \\
\hline $1561-1588$ & 4 & 60 & 64 & 6.3 & 93.7 \\
\hline $1588-1615$ & 1 & 85 & 86 & 1.2 & 98.8 \\
\hline $1615-1643$ & - & 215 & 215 & 0.0 & 100.0 \\
\hline $1643-1670$ & - & 36 & 36 & 0.0 & 100.0 \\
\hline $1670-1698$ & 2 & 27 & 29 & 6.9 & 93.1 \\
\hline $1698-1725$ & 2 & 520 & 522 & 0.4 & 99.6 \\
\hline $1725-1753$ & - & 57 & 57 & 0.0 & 100.0 \\
\hline $1753-1780$ & - & 7 & 7 & 0.0 & 100.0 \\
\hline $1780-1807$ & 1 & 30 & 31 & 3.2 & 96.8 \\
\hline $1807-1835$ & - & 138 & 138 & 0.0 & 100.0 \\
\hline $1835-1862$ & 2 & 65 & 67 & 3.0 & 97.0 \\
\hline $1862-1890$ & - & 250 & 250 & 0.0 & 100.0 \\
\hline 1890 - 1917 & - & 150 & 150 & 0.0 & 100.0 \\
\hline 1917 - 1944 & - & 19 & 19 & 0.0 & 100.0 \\
\hline $1944-1972$ & 2 & 74 & 76 & 2.6 & 97.4 \\
\hline 1972 - 1999 & 1 & 41 & 42 & 2.4 & 97.6 \\
\hline 1999 - 2027 & - & 13 & 13 & 0.0 & 100.0 \\
\hline 2027 - 2054 & - & 3 & 3 & 0.0 & 100.0 \\
\hline 2054 - 2082 & 1 & 22 & 23 & 4.3 & 95.7 \\
\hline $2082-2109$ & - & 12 & 12 & 0.0 & 100.0 \\
\hline $2109-2137$ & 3 & 57 & 60 & 5.0 & 95.0 \\
\hline 2137 - 2164 & - & 13 & 13 & 0.0 & 100.0 \\
\hline 2164 - 2192 & 2 & 7 & 9 & 28.6 & 71.4 \\
\hline $2192-2219$ & 3 & 45 & 48 & 6.3 & 93.7 \\
\hline 2219 - 2246 & 1 & 51 & 52 & 1.9 & 98.1 \\
\hline $2246-2274$ & - & 2 & 2 & 0.0 & 100.0 \\
\hline $2274-2301$ & - & 9 & 9 & 0.0 & 100.0 \\
\hline $2301-2329$ & - & 10 & 10 & 0.0 & 100.0 \\
\hline $2329-2356$ & - & 13 & 13 & 0.0 & 100.0 \\
\hline 2356 - 2384 & - & 4 & 4 & 0.0 & 100.0 \\
\hline $2384-2410$ & - & 5 & 5 & 0.0 & 100.0 \\
\hline 2410 - 2438 & - & 15 & 15 & 0.0 & 100.0 \\
\hline $2438-2466$ & - & 6 & 6 & 0.0 & 100.0 \\
\hline 2466 - 2493 & 2 & 34 & 36 & 5.6 & 94.4 \\
\hline $2893-2521$ & - & 65 & 65 & 0.0 & 100.0 \\
\hline $2521-2548$ & - & 46 & 46 & 0.0 & 100.0 \\
\hline $2548-2576$ & 2 & 28 & 30 & 6.7 & 93.3 \\
\hline $2576-2603$ & 1 & 13 & 14 & 7.1 & 92.9 \\
\hline $2603-2630$ & - & 30 & 30 & 0.0 & 100.0 \\
\hline $2630-2658$ & - & 1 & 1 & 0.0 & 100.0 \\
\hline 2658 - 2685 & - & 5 & 5 & 0.0 & 100.0 \\
\hline $2685-2713$ & - & 3 & 3 & 0.0 & 100.0 \\
\hline $2713-2740$ & 2 & 26 & 28 & 7.1 & 92.9 \\
\hline $2740-2758$ & - & 31 & 31 & 0.0 & 100.0 \\
\hline
\end{tabular}

MONO = total Monoporitesannulatus; ZONO = total Zonocostitesramonae; \%MONO = percentage of Monoporitesannulatus in total of Monoporitesannulatus + Zonocostitesramonae $\%$ ZONO = percentage of Zonocostitesramonae in total of Monoporitesannulatus + Zonocostitesramonae. 
Table 4. Numerical and percentage pollen and spore spectra.

\begin{tabular}{|c|c|c|c|c|c|c|}
\hline DEPTH (m) & SPORES & POLLEN & TOTAL & \%SPORE & \%POLLEN & RATIO P/S \\
\hline 1507 - 1533 & 4 & 6 & 10 & 40.0 & 60.0 & 1.50 \\
\hline 1533 - 1561 & 3 & 4 & 7 & 42.90 & 57.10 & 1.33 \\
\hline 1561 - 1588 & 24 & 8 & 32 & 75.00 & 25.00 & 0.30 \\
\hline $1588-1615$ & 3 & 12 & 15 & 20.00 & 80.00 & 4.00 \\
\hline $1615-1643$ & 9 & 14 & 23 & 39.10 & 60.90 & 1.56 \\
\hline $1643-1670$ & 8 & 10 & 18 & 44.44 & 55.56 & 1.25 \\
\hline 1670 - 1698 & 2 & 4 & 6 & 33.33 & 66.67 & 2.00 \\
\hline $1698-1725$ & 17 & 15 & 32 & 53.13 & 46.87 & 0.88 \\
\hline $1725-1753$ & 9 & 10 & 19 & 47.37 & 52.63 & 1.11 \\
\hline $1753-1780$ & 3 & 1 & 4 & 75.00 & 25.00 & 0.33 \\
\hline $1780-1807$ & 1 & 10 & 11 & 9.09 & 90.91 & 10.00 \\
\hline $1807-1835$ & 3 & 7 & 10 & 30.00 & 90.00 & 2.33 \\
\hline 1835 - 1862 & 3 & 2 & 5 & 60.00 & 40.00 & 0.67 \\
\hline $1862-1890$ & 7 & 14 & 21 & 33.33 & 66.67 & 2.00 \\
\hline 1890 - 1917 & 4 & 11 & 15 & 26.67 & 73.33 & 2.75 \\
\hline 1917 - 1944 & 5 & 5 & 10 & 50.00 & 50.00 & 1.00 \\
\hline $1944-1972$ & 2 & 16 & 18 & 11.11 & 88.89 & 8.00 \\
\hline 1972 - 1999 & 7 & 9 & 16 & 43.75 & 56.25 & 1.29 \\
\hline 1999 - 2027 & 3 & 3 & 6 & 50.00 & 50.00 & 1.00 \\
\hline 2027 - 2054 & 1 & 3 & 4 & 25.00 & 75.00 & 3.00 \\
\hline 2054 - 2082 & 7 & 14 & 21 & 33.33 & 66.67 & 2.00 \\
\hline $2082-2109$ & 4 & 15 & 19 & 26.67 & 73.33 & 3.75 \\
\hline $2109-2137$ & 12 & 13 & 25 & 48.00 & 52.00 & 1.08 \\
\hline 2137 - 2164 & 5 & 7 & 12 & 41.67 & 58.33 & 1.40 \\
\hline 2164 - 2192 & 3 & 7 & 10 & 30.00 & 70.00 & 2.33 \\
\hline $2192-2219$ & 9 & 13 & 22 & 40.91 & 59.09 & 1.44 \\
\hline 2219 - 2246 & 3 & 9 & 12 & 25.00 & 75.00 & 3.00 \\
\hline 2246 - 2274 & 1 & 4 & 5 & 20.00 & 80.00 & 4.00 \\
\hline $2274-2301$ & 5 & 10 & 15 & 33.33 & 66.67 & 2.00 \\
\hline $2301-2329$ & 4 & 5 & 9 & 44.44 & 55.56 & 1.25 \\
\hline $2329-2356$ & 5 & 2 & 7 & 71.43 & 28.57 & 0.40 \\
\hline 2356 - 2384 & 1 & 2 & 3 & 33.33 & 66.67 & 2.00 \\
\hline $2384-2410$ & 3 & - & 3 & 100.00 & 0.00 & 0.00 \\
\hline 2410 - 2438 & 3 & 2 & 5 & 60.00 & 40.00 & 0.67 \\
\hline $2438-2466$ & 7 & 6 & 13 & 53.85 & 46.15 & 0.86 \\
\hline 2466 - 2493 & 6 & 4 & 10 & 60.00 & 40.00 & 0.67 \\
\hline 2893 - 2521 & 2 & 11 & 13 & 15.38 & 84.62 & 5.50 \\
\hline 2521 - 2548 & 8 & 8 & 16 & 50.00 & 50.00 & 1.00 \\
\hline $2548-2576$ & 1 & 4 & 5 & 20.00 & 80.00 & 4 \\
\hline $2576-2603$ & 6 & 7 & 13 & 46.15 & 53.85 & 1.17 \\
\hline $2603-2630$ & 6 & 11 & 17 & 35.29 & 64.71 & 1.83 \\
\hline 2630 - 2658 & 1 & - & 1 & 100.00 & 0.00 & 0.00 \\
\hline 2658 - 2685 & 1 & 3 & 4 & 25.00 & 75.00 & 3 \\
\hline $2685-2713$ & 4 & 3 & 7 & 57.14 & 42.86 & 0.75 \\
\hline $2713-2740$ & 5 & 11 & 16 & 32.25 & 67.75 & 2.20 \\
\hline $2740-2758$ & 7 & 8 & 15 & 46.67 & 53.33 & 1.14 \\
\hline
\end{tabular}


The spores are: Acrostrichum aurreum, Laevigatosporites spp, Verrucatosporites spp, Aletrisporites spp, Stereiosporites spp, Crassoretitrilletes verreadshooverl, Trillete spore, Pediastrum spp, Botryococus braunnii, and Fungal spore. The dynocysts are: Polyspheridium zoharyl and Lycopodiumsporites spp.

This includes abundant land-derived sporomorphs such as Zonocopotites romanae, Sapotaceiodaepollenites sp, Gemmamonoporites spp, Racemonocolporites hians, brackish water swamp species, Pachydermites diederixi, Psilatricolporites crassus and the Pterdophytes spores (Table 1). Common records of microforaminiferal wall linings, dinoflagellate cysts and fresh water algae Botryococcus braunii were occasionally recorded within the well section (Table 2). This assemblage is indicative of shallow marine environment of deposition. The ratio of Monoporites annulatus to Zonocopotites romanae is shown in Table 3, while the numerical and percentage of pollens and spores are shown in 4 . Table 5 is a summary of the biozonaton proposed for the sequences encountered in the studied well. The distribution chart of all the palynomorphs encountered in the studied well and the inferences drawn from them is as displayed in Figure 2.

\section{Systematic}

Division 1: Sporites; Potonie and Gelletich, [14].

Class: Monoletes Ibrahim, [15].

Genus: Verrrucatosporites_spp Potonie, [16].

Plate 1 fig. $d$ and g.

Description: Spore bilaterally symmetrical, heteropolar, boatshaped in the longer equatorial view, monolete; sculpture: Verrucate to gemmate.

Dimension: $45.7 \mu \mathrm{m} \times 49.1 \mu \mathrm{m}$.

Locations: $1507 \mathrm{~m}-2758 \mathrm{~m}$.

Remarks: Common in the well. It occurs in nearly all the sampled intervals within the well.

Botanical Affinity: Resembles the Recent spore of climbing fern Stenochlana palustria (Germeraad, Hopping and Muller [17].

Division 2: Pollennites; Potonie and Gelletich, [14] Angiospermae.

Class A: Monoporatae (Iversen and Troels-Smith, [18].

Genus: Nympheapollis_clarus NAGY [19].

Table 5. Biozonation of the sequences penetrated by Meren 31.

\begin{tabular}{|c|c|c|c|c|c|c|}
\hline & \multirow{2}{*}{ Series } & \multirow{2}{*}{ Sub-series } & \multirow{2}{*}{$\begin{array}{l}\text { Germeraad } \\
\text { et al.; } 1968\end{array}$} & \multicolumn{2}{|c|}{ Evamy et al.; 1978} & \multirow{2}{*}{ Diagnosis/Biodatums } \\
\hline & & & & Zone & Sub-zone & \\
\hline 4943 & & Late & & P800 & P820 & \\
\hline \multicolumn{7}{|l|}{5000} \\
\hline $\begin{array}{l}5500- \\
5570-\end{array}$ & & & & & P780 & $\begin{array}{c}\text {-Top Regular } \\
\text { Occurrence of } \\
\text { Racemonocolporites } \\
\text { hians }\end{array}$ \\
\hline $6000-$ & Miocene & & $\begin{array}{l}\text { Echitricolporites } \\
\text { Spinosus Zone }\end{array}$ & & & \\
\hline $\begin{array}{l}6830- \\
7000-\end{array}$ & & & & P700 & & $\begin{array}{l}\text { Quantitative Top } \\
\text { Occurrence of } \\
\text { Verrutricolporites } \\
\text { rotundiporus }\end{array}$ \\
\hline 8000- & & & & & P770 & \\
\hline 050 TD- & & & & & & \\
\hline
\end{tabular}




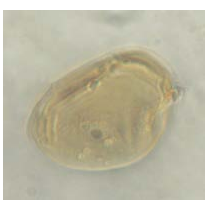

a
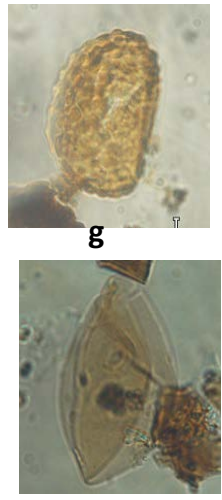

m
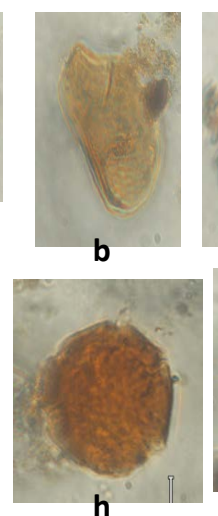

h

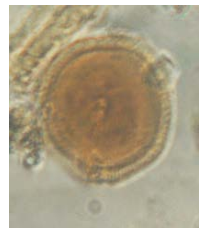

n

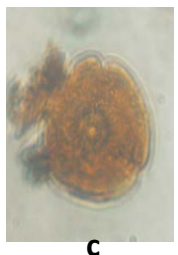

C
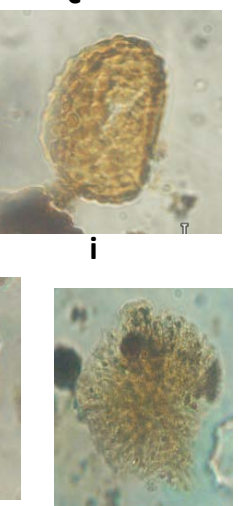

$\mathbf{0}$
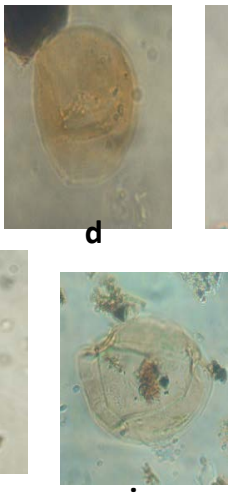

j

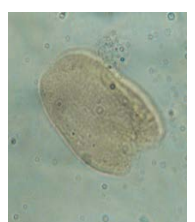

$\mathbf{p}$
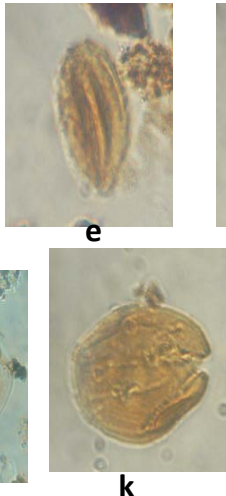

k

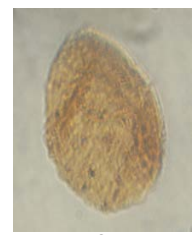

f
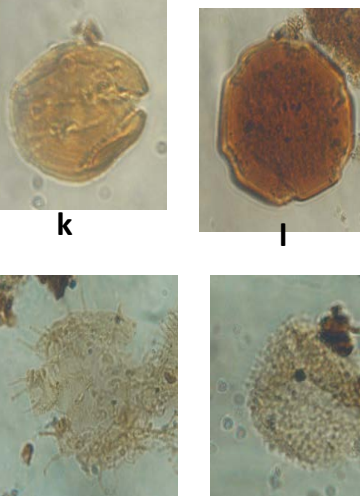

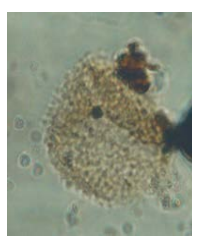

$r$

Plate 1. Palynological assemblages of Meren 31, well.

Plate 1 fig. h and $\mathrm{k}$.

Description: Single grain, large radially symmetrical, circular in outline, and occasionally with concentric rings, with uniformly spaced bacules and psilate.

Dimension: $55.0 \mu \mathrm{m} \times 46.1 \mu \mathrm{m}$.

Lacations: $1561 \mathrm{~m}-1670 \mathrm{~m}$.

Remarks: Abundant and regularly distributed within the well. It is stratigraphically important as a lower Pliocene marker species in the Niger Delta.

Botanical Affinity: It has a close resemblance to the species Nyphaceae.

Genus: Gemmamonoporites (Van Der Hammen and Garcia De Mutis, [20].

Germamonoporites sp Plate 1 fig. b.

Description: Pollen grain globular, heteropolar, monoporate, grain is gemmate, gemmae are of different dimensions.

Dimension: $33.9 \mu \mathrm{m} \times 30.4 \mu \mathrm{m}$.

Locations: Common from 1507 m - 2164 m but rare below.

Remarks: It occurs almost in each depth throughout the well. Rare to common in distribution.

Botanical Affinity: Possibly the pollen of a palmae.

Class B: Tricolporate. Iversen and Troels-Smith, [18].

Genus: Verrutricolporites. Vander Hammen and Wijstra, [21].

Verrutricolporites rotundiporus. Vander Hammen and Wijstra, [21]. Plate 1 fig. c.

Description: Single grain, radially symmetrical, isopolar, spherical to subprolate, outline in polar view is lobate, tricolporate, pores not distinct. Ora marking indistinct, where distinct, they are circular. Bucules thin, Exine verrucate to psilate.

Dimension: $20.5 \mu \mathrm{m} \times 18.8 \mu \mathrm{m}$.

Locations: 1643 m - 2758 m.

Remarks: Shows variation both in size and sculpture. Stratigrapically very important as marker species in the Lower and Middle Miocene of the Niger Delta. It ranges from Late Miocene to Early Pliocene in the studied well.

Botanical Affinity: Identical to the pollen of recent plants-Crenea maritime (Germeraad, Hopping and Muller, [17].

Genus: Psilatricolporites. Vander Hamen, [22].

Psilatricolporites crassus. Vander Hammen and Wijstra, [21] Plate 1 fig. a. 
Description: Single grain, radially symmetrical, spherical to subangular. Grain tricolporate; colpi with straight borders and pointed ends. Ora elongated equatorially. Exine is psilate.

Dimension: $50 \mu \mathrm{m} \times 44.6 \mu \mathrm{m}$.

Locations: $2301 \mathrm{~m}-2329 \mathrm{~m}$.

Remarks: Rare to occasionally abundant variable in shape, sculpture and thickness of coastae. It ranges from Miocene to Pliocene in the Niger Delta.

Botanical Affinity: Closely related to the pollen of Hura sp (especially that of Hura polyandra) (Euphorbiaceae).

Class C: Stephanoporatae. Inversen and Troels-Smith, [18].

Genus: Pachydermites. Germeraad, Hopping and Muller, [17].

Pachydermites diederixi. Germeraad, Hopping and Muller [17].

Plate 1 fig. $f$ and $j$.

Description: Single grain, radially symmetrical, isopolar, oblate to suboblate, has 4.8 spores, aperture is irregular in shape, inner surface is slightly irregular.

Dimension: $35.7 \mu \mathrm{m} \times 42.9 \mu \mathrm{m}$.

Locations: $1507 \mathrm{~m}-1945 \mathrm{~m}$.

Remarks: Recovered at various intervals in the studied well. Common at upper part but rare at the lower part of the well.

Botanical Affinity: Similar to the pollen of symphonia globulifera (Guttiferae). Germeraad, Hopping and Muller; [17].

CLASS D: Periporate. Inverse and Troels-Smith [18].

Genus: Echiperiporites (Van Der Hammen and Wymstra, [21].

Echistephanoporites echinatus. Germeraad, Hopping and Muller, [17].

Plate 1 fig. e.

Description: Single grain, circular in outline, periporate, pore range between $10-24$ or more and are situated at base of spines, ektexinous and edexinus; sculpture spinose, spines are supported by bacules; exine is intrabaculate and spinose.

Dimension: $67.9 \mu \mathrm{m} \times 63.4 \mu \mathrm{m}$.

Locations: $1780 \mathrm{~m}-1807 \mathrm{~m}$.

Remarks: The species has rare occurrence in the well. There is considerable variation in the number of pore size and spinosity. The age is Miocene.

Botanical Affinity: Majority of the pollen resemble the pollen of Thespesia populnea (Malvaceae) (Germeraad, Hopping and Muller, [17]. Larger grains are closer to Hibiscus tiliaceus.

\section{Discussion}

\subsection{Palynological Biozonation}

The well section is sub divisible into two biozones: P800 and P700 zones. The P820 subzone was only recognized within the P800 zone while the P700 is further subdivided into P780 and P770 subzone of [4]. This sequence is further correlated with the Echitricolporites spinosus zone [17]. The zone and subzones recognized are discussed briefly below and represented graphically in Table 5 and Figure 2.

\section{ZONE P800}

Subzone P820

Interval: 1507 - $1698 \mathrm{~m}$.

Age: Late Miocene

Diagnosis: This is the youngest subzone recognized in the studied section of the Meren-31st-2 well. The top of this subzone is placed at the depth $(1507 \mathrm{~m})$ of the first sample analyzed while the base is defined by the top regular occurrence of Racemonocolpites hians. This interval is further characterized by the regular records Gemmamonoporites sp and the abundant numbers of Zonocoltites ramonae.

\section{ZONE P700}

Subzone P780

Interval: $1698 \mathrm{~m}-2082 \mathrm{~m}$.

Age: Middle Miocene 
Diagnosis: The top of this subzone is marked by the top regular occurrence of Racemocolpites hians at 1698 $\mathrm{m}$ while the base is defined by the quantitative top occurrence of Verrutricolporites rotundiporus at $2082 \mathrm{~m}$. This subzone is further confirmed by the regular and abundant records of Verrutricolporites rotundiporus, Psilatricolporites crassus and Acrostichum aureum.

(iii) Subzone P770

Interval: $2082 \mathrm{~m}$ - $2758 \mathrm{~m}$

Age: Middle Miocene

Diagnosis: This is last and oldest subzone recognized in Meren-31st-2 well. The top of this subzone was defined by the quantitative top occurrence of Verrutricolporites rotundiporus.

\subsection{Palaeoclimate}

The climatic fluctuation in Meren 31st-2 well is discussed according to the "floral" zones.

\section{Depth 2758 m - 2082 m}

At the total depth of the well (2758 m), there was a very low to zero percentage of grass pollen, Monoporites annulatus, with an observed increase in the percentage ratio of Monoporites annulatus to Zonocostites ramonae from $0 \%$ to about $7.1 \%$ from $2713 \mathrm{~m}$ up to $2576 \mathrm{~m}$ and peaked at $2219 \mathrm{~m}$ (about 28.6\%) (Table 3). This increase was accompanied by a rather more consistent record of mangrove pollen, Zonocostites ramonae, with sharp increase in numerical quantities of this wet climate indicator at $2356 \mathrm{~m}$ and between $2493 \mathrm{~m}$ and $2521 \mathrm{~m}$ where (it)Cyperaceapolis spp., Pteris attained the highest quantitative occurrence within this "Floral" zone with 65 counts (Table 3). Within this zone, the rare occurrence of marine element, dinocyst Lycopodiumsporites spp was also recovered (Table 3). A wet condition would have been suggested for this zone due to the regular occurrence of mangrove pollen and abundance of fresh water alga, Botryococcus braunii along with brackish water swamp species, Pachydermites diederixi and Psilatricolporites crassus, which were abundant within this zone coupled with the rare occurrence of Gramineae pollen, but for the rare record of Cyperraceaepollis spp., which is a humid climate indicator [23] [24]. The zone was probably experiencing a humid climate during this time. According to [25], the abundance of Rhizophora pollen above 40\% (Table 4) in sediments indicates a good representation of mangrove swamp, suggesting a humid tropical lowland climate during the deposition of the mentioned interval.

Some of the savannah pollens recorded in the above named zone include Corylus spp., etc while the wet climate indicators are freshwater swamp rainforest species like Sapotaceae, Verrutricosporite rotundiporus, Gemmamonoporites spp., Striatricolpites catatumbus and a few others. The presence of the dinocyst species, Lycopodiumsporites spp suggests sediment deposition in a shallow marine environment with frequent freshwater incursions and lowered sea levels following glacial maxima [26].

\section{Depth 2082 m - 1698 m}

There was a sharp quantitative (numerical) increase in mangrove pollen Zonocostites ramonae from about 65 counts at $2493 \mathrm{~m}$ to 520 counts at $1698 \mathrm{~m}, 250$ counts at $1862 \mathrm{~m}$ and 138 counts at $1807 \mathrm{~m}$, with a gentle downhole increase in Monoporites annulatus (Table 3) within this zone. This observation could be hardly visible when considering it in terms of percentage composition of the total mangrove pollen and Gramineae pollen, where Zonocostites ramonae attained $100 \%$ in some depth within this floral zone (Table 3 ). There were also noticeable fluctuations in the occurrence of ferns, Laevigatosporites spp., Verrucatosporites spp. and Stereiosporites spp. within this interval.

This zone is probably a dry climate phase with warm temperatures. In a study by [27] in SW Turkey high percentages of Gramineae pollen types in sediment was taken to point to drier local conditions. A noticeable presence of savanna species Echistephanoporites echinatus, further confirms the prevalence of a dry climate within this interval. Other important savanna species occurring within this zone include Concentricytis spp., Cyperaceaepollis spp., Corylus spp., Pteris spp. and more. However, a few rainforest/fresh water swamp species were recorded within this zone. These include Canthium spp., Retibrevitricolporites spp., Psilatricolporites onitshaensis etc., (Table 1) and a rare to common record of Botryococcus braunii. The occurrence of small quantities of mangrove pollen in this zone was probably due to minor local short-lived transgressions of the sea, thereby allowing only very limited extension of mangrove vegetation.

Depth 1698 m - 1524 m

By the time of deposition of the sequences within this interval, the pollen record indicates that mangrove 
swamp forest vegetation was now well established, with the quantitative occurrence of Zonocostites ramonae reaching its highest numerical value (520 counts) at $1698 \mathrm{~m}$ (Table 3). So also was a high occurrence of fresh water swamp species, Sapotaceae, Retitricolporites irregularis, Retibrevitricolporites protudens etc., with rare occurrences of other fresh water sporomorphs of Verrutricolporites rotundiporus, Gemmamonoporites spp., Verrutricolporites microporus, Magnastriatites howandi etc. Also recorded were rare to common occurrences of brackish water swamp species of Pachydermites diederixi and Psilatricolporites crassus and fresh water algae, Botryococcus braunii. It is worthy to note the increase in abundance of pteridophytes (fern spores), Laevigatosporites spp., Verrucatosporites spp. and Stereiosporites spp. coupled with an almost consistent occurrence of Acrostichum aureum and rare occurrences of lowland rainforest species like Nympheaepollis clarus, Echistephanoporites echinatus, Racemonocolpites hians, Canthium spp., etc. (Table 1 and Figure 2). There is also an overall increase in the recorded quantities of grass pollen, Monoporites annulatus, both numerically and in ratio to mangrove pollen. There was a visible common to abundant occurrences of Corylus spp., Cyperaceaepollis spp. and Pteris spp., and rare to common occurrences of Ctenolophondites costatus, Charred Gramineae cuticle, Chenophondipollis spp., Elaeis guineensis, Numulipollis neogenicus, Peregrinipollis nigericus etc., which are all savanna species (Table 1 ).

An initial rise in sea level with the mangrove vegetation increasing in extent is suggested for this zone. The fluctuations in percentage occurrence of Zonocostites ramonae may probably be a result of variations in the intensity and extent of the tidal streams thereby causing fluctuations in the extent of mangrove forest. This rise and fall of the tides may also bring about drier conditions resulting in a reduction of forest vegetation and subsequently promoting expansion of the savanna [26]. This agrees with the reports of [23] which revealed cyclic fluctuations in the vegetation and continental climatic condition of North-West Africa in the Pliocene, when river discharge ceased, wind transport of pollen grains prevailed over fluvial transport.

\section{Conclusions}

The recovered palynomorphs in the studied well consists of abundant land-derived sporomorphs such as Zonocopotites romanae, Sapotaceiodaepollenites sp., Gemmamono porites spp., Racemonocolporites hians; brackish water swamp species, Pachydermites diederixi, Psilatricolporites crassus; Common records of microforaminiferal wall linings, dinoflagellate cysts; and rare occurrence of fresh water algae Botryococcus braunii.

Based on the top regular occurrence of Racemonocolpites hians and Racemocolpites hians, the P820 and P780 subzone, respectively were recognized within the section of the well studied. The top of subzone P770 was defined by the quantitative top occurrence of Verrutricolporites rotundiporus, which enabled assignment of middle Miocene to the deepest part of the well.

Paleobathymetric analysis based on microfloras indicated that the majority of the spores and pollen species showed minor variations in abundance and diversity within the studied section of the well. Abundant occurrence of Monoporites annulatus in some sections of the well enabled delineation of the sequences that were deposited under wet conditions during the Miocene. In most cases, such interval is characterized by the dominant occurrence of pollen grains of Rhizophora spp., Zonocostites ramonae, and spores of pteridophytes and fungi. The sequences within interval $2082 \mathrm{~m}$ - $1698 \mathrm{~m}$ were probably deposited under a dry climatic phase with warm temperature based on the occurrence of Echistephanoporites echinatus Concentricytis spp., Cyperaceaepollis spp., Corylus spp., and Pteris spp.

\section{Acknowledgements}

Many thanks to the Department of Applied Geology, Federal University of Technology, Akure for permitting the use of the samples provided by Chevron Nig. Limited for research purposes. Dr. Fadiya facilitated the use of Crystal Age Limited Laboratory for the analysis. These are all appreciated.

\section{References}

[1] Larue, D.K. and Legarre, H. (2004) Flow Units, Connectivity, and Reservoir Characterization in a Wave-Dominated Deltaic Reservoir: Meren Reservoir, Nigeria. American Association of Petroleum Geologists Bulletin, 88, 303-324.

[2] Esan, A.E. (2002) High Resolution Sequence Stratigraphic and Reservoir Characterization Studies of D-07, D-08 and E-01 Sands, Block 2 Meren Field, Offshore Niger Delta. NAPE. Texas A\&M University, College Station. 
[3] Knap, W.A. (1971) A Montane Pollen Species from the Upper Tertiary of the Niger Delta. Journal of Mining and Geology, 6, 23-29.

[4] Evamy, B.D., Haremboure, J., Kamerling, P., Knaap, F.A., Molloy, F.A. and Rowland, P.H. (1978) Hydrocarbon Habitat of Tertiary Niger Delta. American Association of Petroleum Geologists Bulletin, 62, 1-39.

[5] Legoux, O. (1978) Quelques Especes De pollen Caracteristiques De Neogene Du Nigeria. Bull. Cent. Rech. Explor. Prod. Elf-Aquitaine, 2, 265-317.

[6] Sowunmi, M.A. (1981) Aspects of the Late Quaternary Environmental Changes in West Africa. Journal of Biogeography, 8, 457-474. http://dx.doi.org/10.2307/2844565

[7] Oboh, F.E. (1992) Middle Miocene Palaeoenvironments of the Niger Delta. Palaeogeography, Palaeoclimatology, Palaeoecology, 92, 55-84. http://dx.doi.org/10.1016/0031-0182(92)90135-R

[8] Frankl, E.J. and Cordry, E.A. (1967) The Niger Delta Oil Province: Recent Developments On-Shore and Off-Shore. 7th World Petroleum Congress, Mexico City, 2-9 April, 195-209.

[9] Short, K.C. and Stauble, A.J. (1967) Outline of the Geology of Niger Delta. American Association of Petroleum Geologists Bulletin, 51, 761-779.

[10] Weber, K.J. and Daukoru, E. (1975) Petroleum Geology of the Niger Delta. Jour. Min. Geol., 12, 9-12.

[11] Avbovbo, A.A. (1978) Tertiary Lithostratigraphy of Niger Delta. American Association of Petroleum Geologists Bulletin, 62, 295-300.

[12] Knox, G.J. and Omatsola, E.M. (1989) Development of the Cenozoic Niger Delta in Terms of the "Escalator Regression” Model and Impact on Hydrocarbon Distribution. In: van der Linden, W.J.M., et al., eds., Proceedings of KNGMG Symposium on Coastal Lowlands, Geology, Geotechnology, Kluwer Academic Publishers, Dordrecht, 181-202.

[13] Tuttle, L.W.M., Charpentier, R.R. and Brownfield, E.M. (1999) The Niger Delta Petroleum System: Niger Delta Province, Nigeria Cameroon and Equatorial Guinea, Africa. US Geological Survey Open-File Report 99-50-H, Denver, 70.

[14] Potonie, R. and Gelletich, J. (1933) Uber Pteridophyten-sporen einer eözaner Braunkohle aus Dorog in Ungarn. S.B. Berlinische Gesellschaft Naturforschender Freunde, 33, 517-526.

[15] Ibrahim, B. (1993) Sporenformen des Aegirhorizonts des Rubrvrviers. Konrad Triltsch, Wurzburg, 46, 8.

[16] Potonie, R. (1956) Synopsis der Gattungen der sporae dispesae I. Geol. Jahrb. Beih, 23, 1-103.

[17] Germeraad, J.H., Hopping, C.A. and Muller, J. (1968) Palynology of Tertiary Sediments from Tropical Areas. Review of Palaeobotany and Palynology, 6, 189-348.

[18] Iversen, J. and Troels-Smith, J. (1950) Pollenmorfogiske definitioner og typer. Danmarks geologiske Undersøgelse, 4, No. 8.

[19] Nagy, E. (1969) Occurrence of the Genus Ephedrites in the Neogene of Hungary. Ghana Palynologica, 4, $277-280$. http://dx.doi.org/10.1080/00173136309436749

[20] Van der hammen, T. and Garcia de mutis, G. (1965) The Paleocene Pollen Flora of Colombia. Leidse Geologische Mededlingen, 35, 105-116.

[21] Van der hammen, T. and Wijstra, T.A. (1964) A Palynological Study of the Tertiary and Upper Cretaceous of British Guiana. Leidse Geologische Medeleingen, 30, 209-231.

[22] Van der hammen (1956) El desarrollo de la flora Micropaleontol. Columbiaus en los perindos geologieos, 29, 61-83.

[23] Dupont, L.M. and Agwu, C.O.C. (1991) Environmental Control of Pollen Grain Distribution Patterns in the Gulf of Guinea and Offshore NW-Africa. Geologische Rundschau, 80, 567-589.

[24] Tossou, M.G. (2002) Recherche palynologique sur lavégétation holocène du sud-Bénin (Afrique del’Ouest). Ph.D. Thesis, Proefschrift Universite de Lome, 136.

[25] Sowunmi, M.A. (1981) Aspects of Late Quaternary Vegetational Changes in West Africa. Journal of Biogeography, 8, 457-474. http://dx.doi.org/10.2307/2844565

[26] Ige, O.E., Datta, K., Sahai, K. and Rawat, K.K. (2011) Palynological Studies of Sediments from North Chioma-3 Well, Niger Delta and Its Palaeoenvironmental Interpretations. American Journal of Applied Sciences, 8, 1249-1257. http://dx.doi.org/10.3844/ajassp.2011.1249.1257

[27] Vermoerea, M., Degryseb, P., Vanheckec, L., Muchezb, Ph., Paulissend, E., Smetsa, E. and Waelkense, M. (1999) Pollen Analysis of Two Travertine Sections in Basköy (Southwestern Turkey): Implications for Environmental Conditions during the Early Holocene. Review of Palaeobotany and Palynology, 105, 93-110. http://dx.doi.org/10.1016/S0034-6667(98)00068-2 
Scientific Research Publishing (SCIRP) is one of the largest Open Access journal publishers. It is currently publishing more than 200 open access, online, peer-reviewed journals covering a wide range of academic disciplines. SCIRP serves the worldwide academic communities and contributes to the progress and application of science with its publication.

Other selected journals from SCIRP are listed as below. Submit your manuscript to us via either submit@scirp.org or Online Submission Portal.
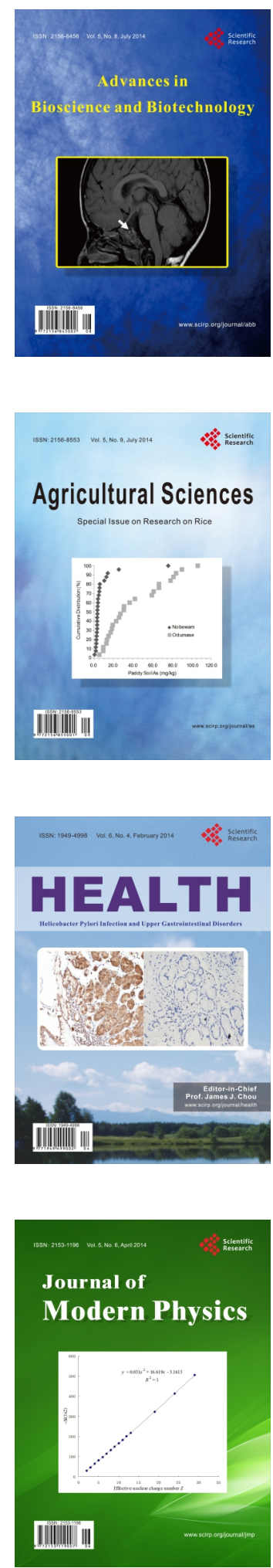
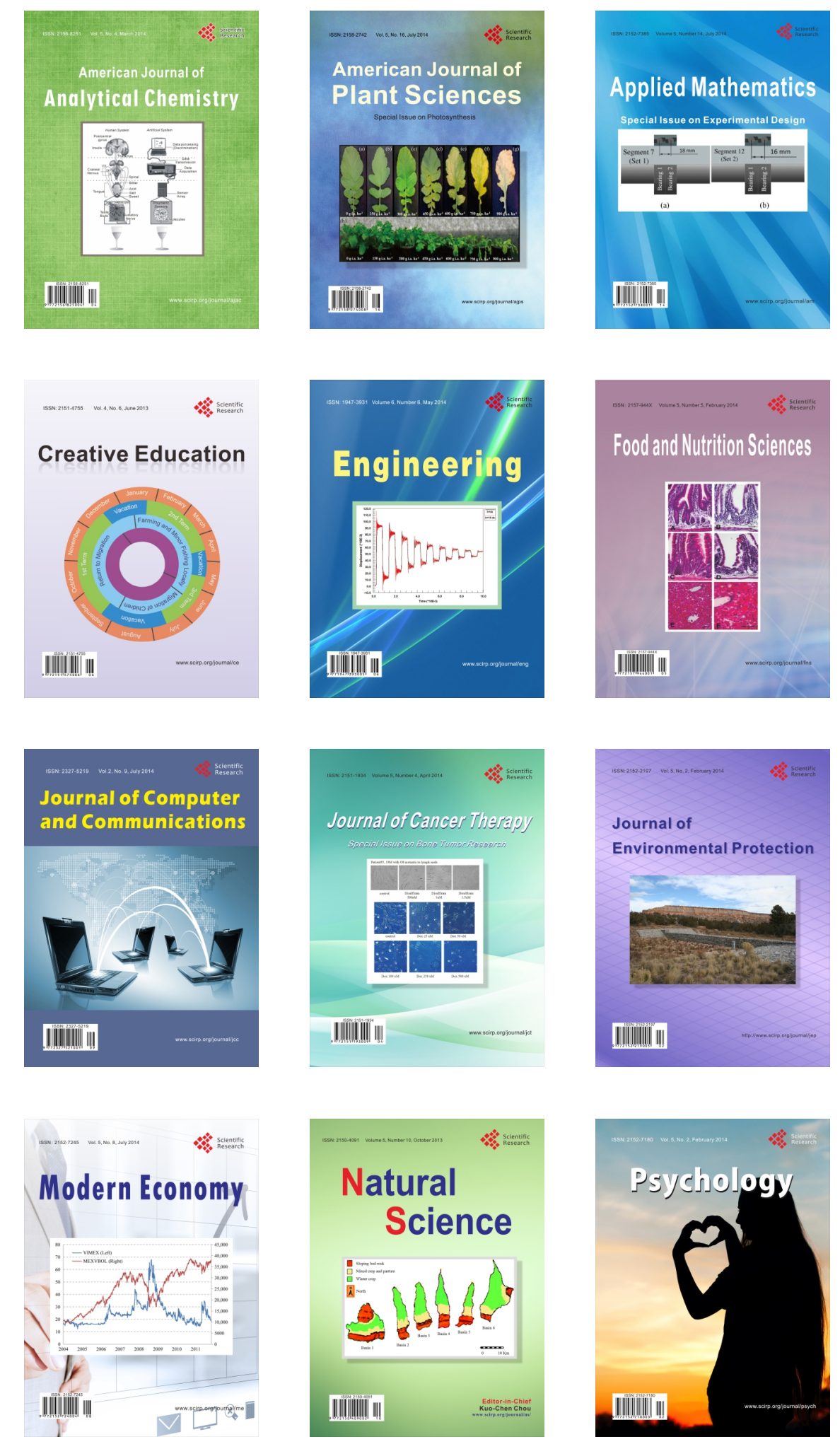